Petr Wawrosz,

Dr.Sc., University of Finance and Administration, Czech Republic

\title{
PRODUCTIVE OF THE SERVICE SECTOR: THEORY AND PRACTICE OF CORRUPTION DECLINING
}

\begin{abstract}
Corruption contracts are, throughout the democratic world, illegal and considered immoral. Their participants thus cannot use standard procedures to find a second party, to negotiate the content of the contract, to check if it performs what was promised, and to enforce the promises. This increases the risks associated with the contract. Illegality or immorality of the contract makes both parties more vulnerable - each party can threaten to reveal the contract and denounce the second party. Connecting a corruption contract with a previously established legal contract is usually seen as the best way to reduce risks and to reinforce the corruption contract. Owing to legal contacts and contracts, potential parties interested in corruption know where they should seek a counterparty and what to offer. At the same time, the corruption contract is tied to legal contracts, and failure to fulfil conditions of the corruption contract may put such legal contract at risk, therefore there is a higher probability that both parties to the corruption contract would fulfil what was promised and that there will be no extortion by any of the parties to demand additional fulfilment after the end of the corruption contract or that the corruption contract will not be disclosed. This paper presents the opposite approach in which a corruption contract is established as the first and it creates the base for further often legal but immoral contracts. All contracts lead to the mutually advantageous affinity of all its participants who often become members of corruption networks. The article presents the model when a blackmailed or dependent person must participate in corruption contracts, otherwise, it faces serious problems. But sooner or later, participation will begin to bring him benefits, so he becomes dependent on the network, although initially, he had moral inhibitions to participate in its activities. The subjects looking a counterparty of the corruption contract thus often create the environment of dependency and blackmailing and when people that are obliged to corruption lose their scruples and they see corruption as the common behaviour. Our model comes from real corruption networks in the Czech Republic. Some of them are briefly analysed. Theory of corruption must pay higher attention to all factors contributing to the spread of corruption behaviour, including mutual dependence and extortion.
\end{abstract}

Keywords: blackmailing, corruption, corruption networks, corruption risks, mutual dependency.

Introduction. Corruption has existed in human societies since the beginning (see e.g. Dion, 2010, 2013). The main reason for this is that corruption, as well as other undesirable forms of behaviour, are advantageous for the participants (e.g. Becker, 1968). However, corruption contracts are, at least in democratic countries, riskier than others. As they violate generally recognized rules of human behaviour, they are usually illegal or considered immoral and they are of a riskier nature. When economic theory analyses how the risks connected with a corruption contract are eliminated, models are usually presented where corruption contracts relate to a previously established legal contract (e. g. Lambsdorff, 2007, 2015). The main aim of the article is to develop the opposite approach and show the model where a corruption contract can be based on the mutual dependency and extortion and that it creates space for other contracts (both legal and illegal, respectively moral and immoral). Such contracts commonly include more people who create corruption networks. The network provides benefits to its members at the expense of nonmembers and makes members mutually dependent. If a member of the network breaks the rules, they can be punished and lose advantages connected with membership. All this makes the corrupt contract more stable and less risky. The model further shows that the first step of how to force a person to participate in a corrupt contract is to make them dependent or blackmailed. The paper is divided into four parts, including literature review, research methodology, results, discussion, and conclusion. The literature review includes the definition of corruption, its negative consequences and explanation of why it cannot be seen as the appropriate form of behaviour. The research methodology identifies the risk of a corruption contract and standard ways of their overcoming. It further introduces own model where people are blackmailed or

Cite as: Wawrosz, P. (2019). Productive of the Service Sector: Theory and Practice of Corruption Declining. Marketing and Management of Innovations, 4, 269-279. http://doi.org/10.21272/mmi.2019.4-21 
dependent and they are due to these factors forced to participate in corruption activities. Dependence along with recognizing corruption activities as common behaviour leads to a higher willingness to participate in corruption and other illegal or immoral behaviour and to create corruption networks. The results give some examples of corruption networks in the Czech Republic that are in accordance with our model. The discussion and conclusion include the general summary of the paper, research limitations, and suggestions for future research.

Literature Review. A review of the literature starts with the topic definition of corruption. It must be emphasized that such definition has proven difficult. Cockcroft $(2012$, p. 3) observes that definitions of corruption range from «the decay of society to the single act of bribery». Corruption includes such a wide range of behaviours and activities making it difficult to reach a consensus. In the past, definitions very often confined corruption only to the public sector. For instance, Shleifer and Vishny $(1998$, p. 91) offer a simple definition of corruption as the «sale by government officials of government property for personal gain». This definition, while concise, has limitations. First, what is classified as government property? Does the provision of services and the granting of access count under this definition? This definition is also silent on whether the act violates the law or the common good. The above definition is very similar to the definition of corruption previously used by the World Bank, which is the "abuse of public office for unauthorized private gain» (World Bank, 2000). By using the term abuse instead of a sale, this definition covers a broader category of behaviour. This definition also incorporates the term unauthorized, which allows researchers to compare the act with the legal code. Jain (2002, p. 73) provides a nearly identical definition. For him, corruption «is an act in which the power of the public office is used for personal gain in a manner that contravenes the rules of the game». However, is there a difference between unauthorized behaviour and behaviour that contravenes the rules of the game? «Unauthorized behaviour» implies strict legal sanction, whereas «contravenes the rules of the game» can be interpreted to include informal norms inherent to any institution. According to these definitions, as mentioned above, only government officials are guilty of corruption. Private actors, which can also be a beneficiary of a corrupt act, are absolved of responsibility. This is a serious shortcoming when defining corruption in that manner, as private actors may initiate a corrupt exchange with a public employee. Furthermore, it is not clear what classifies as abuse or circumvention. Does this have to do with circumventing the law or acting in a manner inconsistent with the common good? Currently, used definitions usually recognize that corruption can occur everywhere and at any time. Transparency International, an organization focused on the fight against corruption, now defines (e.g. Transparency International, 2015, p.3) corruption as «abuse of entrusted power for private gain». Similarly, Karmann et al. (2016, p. 223) describe corruption as «illicit use of one's position or power for perceived personal or collective gain». However, abuse or illicit use can still have many aspects to it that do not include corruption in the way most people usually understand it - a contract of at least two subjects that is convenient for both and breaks some generally acceptable principle of human behaviour and thus cannot be recognized as a universal manner of conduct. The above-mentioned definitions also concentrate on the role of the subject with power and neglect the role of the subjects benefiting from the corrupt behaviour of the subject with power. Further, they do not pay attention to other subjects that are harmed by corrupt behaviour.

Therefore, corruption is defined as «any behaviour that deviates from generally accepted formal and informal obligations to achieve private gain. Corruption is a form of business. On the one hand, there is a subject possessing a certain form of power whether it is of action or decision. This person is called «the corrupt agent» and they can include more than one person (e. g. two or more government officials). The corrupt agent is violating their duties and obligations because they or another subject (e. g. a corrupt relative) has or may benefit from a violation. On the other hand, there is a second subject called «the corrupting agent» - again several people (e. g. players of a sports club) can represent it. The corrupting agent gives or promises to benefit the corrupt agent if the corrupt agent violates their duty. The violation 
is beneficial for the corrupting agent. By the actions of the corrupt agent, the corrupting agent or some related agent such as a relative may gain some benefits at the expense of a third party that does not participate in corruption». To provide clarity let's give a simple example of a corruption contract. Parents owning a travel agency ask two teachers to falsify school results of the parents' child. The teachers agree and the child can successfully apply to university. Relatives of both teachers receive free summer vacations provided by the parents' agency in return. The teachers represent the corrupt agent, the parents are the corrupting agent. Neither teachers nor parents have directly benefited from their behaviour but somebody else has. The contract harms other students. The parents' child is unjustly favoured over them. Corruption has many negative consequences (e.g. Lambsdorff, 2007; Rose-Ackerman and Palifka, 2016). Most of the literature insists that corruption lowers economic growth and GDP per capita because it reduces the incentive for private investment, distorts public investment decisions, and induces talented people to undertake rent-seeking activities. It further reduces innovation-related activities of companies, substantially affects income distribution and increases income inequality, which will change the structure of investment when projects are supported that have higher corruption potential. But some studies (e.g. Huntington, 1968; Lui, 1985; Lein, 1986; Meon and Sekkat, 2005; Johnson et al., 2014) argue that corruption has some positive consequences - it "greases the wheel» - it can be conducive to entrepreneurs' activity and generally contributes to higher GDP growth, better firm performance or standard of living, especially in countries whose institutions are weak and function poorly (Acemoglu and Verdier, 2000; Meon and Weill, 2010). Empirical results are ambiguous. It depends, as Hanousek and Kochanova (2015) points, on the sample of investigated countries or firms, the period and other factors. Some conclusions (e. g. Dejardin and Laurent, 2016) indicate that corruption can help entrepreneurs in situations where public-sector regulation creates only appropriate obstacles for doing business and when corruption is not a widespread phenomenon. However, it can be objected, even in this situation, that:

1. Regulations, public-sector size and power are not exogenous variables. A willingness to overcome public-sector obstacles by corruption results in the public sector creating further obstacles to achieve more resources from corruption.

2. It is not clear whether companies using corruption to achieve their goals achieve better results than those subjects that do not participate in corruption. A corrupt agent can see the participation of a corrupting agent in corruption activities as a sign of weakness and can force the corrupting agent to pay further bribes or to give other benefits even in situations where the corrupting agent has fulfilled what was arranged.

3. Corruption changes the structure of the market. Firms that do not participate in corruption can limit their activities partially or completely, which affects the efficiency of the market and the whole economy.

It would be a mistake to restrict the harmful nature of corruption solely to the above-mentioned points. Another damage is equally serious - in particular, the fact that corruption puts people on an unequal playing field. Due to corruption, people 's place on a hierarchy can be determined by their willingness and ability to be corrupt or their connections to other corruption networks (e.g. kinship). Corruption limits equality of opportunities and limits the existence of a state where every person can freely pursue their goals. In many cases, the objective can only be achieved through corrupt conduct. Skills are less valuable: the ability to be corrupt is more important. People cannot be corrupt to the same degree, and the environment prefers those who are able or willing to participate in corruption. The given inequality of the position naturally has its economic consequences. Because of the corruption, those who are corrupt may be richer, have higher income or own more, etc. There is mutual causality - corruption leads to higher economic inequalities (measured by, for example, the Gini coefficient), and this higher economic inequality further reinforces and encourages corruption. Corruption is therefore procedurally unfair as it violates the principle of impartiality (for details see Rawls, 1999). Besides, it is unjust from the distribution point of view 
because it represents means of social and economic distribution that goes against generally accepted criteria of distributive justice such as merit, need and equality.

Zelekha (2013) considers the decline of generalized trust in society as the main damage done by corruption. From the article point of view, it must be emphasized that any social system needs to be trusted because it will not perform the tasks at hand in an environment of mistrust, even if it strives to do so. In an environment of mistrust, the outputs of that system will be questioned, and will not be taken as relevant. If corruption in the society exceeds a critical threshold, the members of the society will no longer put trust in the society, and this will result in the government's inability to properly rule and put the fundamental characteristics of democracy at risk. Similarly, Di Tella and MacCulloch (2006) mention that corruption undermines faith in capitalism. Corruption also signals that any means can be used to achieve human objectives. Corruption can have additional social costs such a society losing faith in the concept of justice and people being viewed merely as means and not ends in themselves. Corruption also leads to confusion in people's behaviour, making them live in an unbalanced world where different standards are applied to the same actions. In this regard, the argument that there is no point in fighting corruption if the country's economy is growing must be refuted. Rose-Ackerman and Palifka (2016) rightfully state that the fact that a country achieves economic growth, even though corruption is deeply rooted in the country, is not an argument for not fighting corruption. Economic growth is not the only that people should hold. Corruption, even in the face of economic growth, undermines the legitimacy and harms those who are not involved in it or are only involved to a small degree.

In terms of ethics, corrupt practices contradict generally accepted principles of human behaviour. Such principles mean universal rules that are observed in most human societies. They can be defined as rules that meet the requirements of Kant's categorical moral imperative (e.g. Kant, 2016). In the case of corruption, the following question can be asked: would I want everyone to be corrupt? If anyone wanted this, they would not be able to achieve their goals. As Kaufmann (1997) notes, a society cannot be based solely on corruption. Lambsdorff (2007) points to the fact that those involved in corrupt contracts try to make sure that the obligations agreed in such contracts are fulfilled in order and not to be disturbed by other corruption contracts. At least, they fight corruption in their interest. A society where everyone is involved in corrupt transactions is logically impossible. As a result, it can also be concluded that corrupt practices conflict with the categorical imperative or generally accepted principles of human society.

Methodology and research methods. The fact that corruption cannot be a universal principle of human behaviour is reflected in the risks of the corruption contract. From economics, corruption is rational economic behaviour. Both subjects of corruption (the corrupt agent and the corrupting agent) assume that corruption will improve their current situation relative to what would have been otherwise. Of this, they can, of course, be wrong, but they do not engage in corruption if they do not believe that corruption is beneficial to them. The assumption can be aptly characterized by the following quotation: "Corruption is a crime of reason, not passion» (e.g. Fisman and Miguel, 2008; Klitgaard, 2011). However, as noted by Lambsdorff (2002), a corruption contract is, at least in democratic countries, different from a common contract in several aspects: 1. It is not enforceable. 2. It is hidden. 3. It continues - it does not terminate upon the fulfilment of what the parties agreed upon. These differences increase both the risks and costs of the corruption contract. The unenforceability means that neither the corrupt agent nor corrupting agent has the legal means to make the second part of the contract to perform what they agreed to do. The hidden nature of the contract excludes standard procedures to be used for the entering into and performance of the contract - such as advertising, a tender to choose the counterparty, informing of the contract progress and open control procedures. The continuation of the contract following the mutual performance means that both subjects can blackmail each other by disclosing their involvement in the corrupt activities or may require another performance as a condition for non-disclosure. There may even be disclosure without blackmailing if one of the parties is not satisfied with the performance. Lambsdorff (2007) here elaborates 
that there are risks at the initiation of the corruption contract, during its performance and following its termination. When looking for a counterparty, the interested party must remain in hiding, while taking the risk that the approached party will not be interested and will expose them. The corrupting agent should know whether the potential corrupt agent has the relevant power and if it is willing to abuse it. On the other hand, the corrupt agent should have certainty that the corrupting agent is not trying to discredit them. Besides, the amount which is offered by the corrupting agent to the corrupt agent may pose a problem. If it is too low, the corrupt agent may turn down the offer; if it is too high, the corrupting agent excessively loses funds. The question is also what the benefits for the corrupt agent should be - the corrupt agent does not have to be exclusively interested in money. The person seeking information about a potential corruption counterparty cannot use public advertisements or other standard market procedures.

During the realization of their corruption, there is a risk that one of the parties will not keep to their promise, particularly when the performance is not simultaneous, and the promise may not be legally enforced. The contract should define when and how exactly the corrupt agent violates their obligations and when the corrupting agent meets their obligation to the corrupt agent or someone else. But such a specification is often difficult due to the hidden nature of the contract, which creates an environment for opportunistic behaviour. When the contract terminates, there is the risk of blackmailing mentioned above connected with the requirement for additional performance, or a general threat that the corruption behaviour will be disclosed. Economic theory (e. g. Lambsdorff, 2007; Edelbacher et al., 2016) describes many ways in which the risk connected with corruption contracts can be overcome. Problems connected with finding a counterparty to the contract may be solved, for example, via rumours about the potential corruptibility of a person. Such rumours should be understood by the potential partner as an offer. A lavish lifestyle can be one way to spread such rumours since living beyond one's official sources of income is an apparent hint of one's corruptibility. Another means of spreading information is to engage the services of a middleman who may not have to fear sanctions for advertising corrupt services. During the corruption contract, the bribe or another corruption fulfilment can be substituted for a loan or other legal payment, or another legally enforceable payment. Both parties may provide some security to avoid the risk of the counterparty failing to hold to their promise. Following contract termination, the risk of blackmailing and disclosure can be reduced if the parties that may be put at risk by blackmailing or disclosure continue to maintain their relationships. Based on empirical data, the literature (e.g. Rose-Ackerman, 1999; Lambsdorff, 2007; Edelbacher et al., 2016) concludes that the best method to reduce the risks mentioned above is to connect a corruption contract with a long-standing (usually legal) relationships that exist before the corruption contract. The most obvious opportunities for corruption, therefore, arise between partners with already established legal relationships. As their legal relationships deepen, they may encounter the opportunity to collude at the expense of a third party (e.g. their employee or somebody else who is harmed by their corruption). To be clear, it is not corruption but a legal contract that brings people together in the first place. A legal relationship represents a vehicle for establishing a corrupt relationship and the latter is parasitically linked to the former. Legality and corruption cease to be two opposing forms of relationships. Lambsdorff (2007) presents the conclusion on the findings of the German police that the parties to a corruption contract have known each other for less than one month before entering into the corruption contract in only $20 \%$ of discovered cases. They usually have known each other much longer and only when they knew each other well enough they had enough confidence to make a corruption contract.

In general, the standard explanations of how to eliminate the risks of a corruption contract can be summarized as long-term usually legal contacts and contracts, based on which relationships and ties are established between their participants, thereby creating conditions for the emergence of corruption contracts. Due to legal contracts and contracts, a person potentially interested in corruption knows where to look for counterparty and what to offer them. At the same time, the corruption contract is tied to legal contracts: failure to fulfil the terms of the corruption contract would put these legal contracts at risk. This 
creates a greater likelihood that both parties to the corruption contract will fulfil what they promised and that after the termination of the corruption contract there will be no extortion to request further action by threatening to disclose the existence of the corruption contract. The paper presents the opposite approach showing that a corruption contract can serve as a basis for further contracts, or that long-term relationships may arise from the corruption contract, with close ties being established among corruption participants even in the case when participants do not know each other before the contract. The risks associated with the corruption contract can, in our opinion, be limited at the very beginning of the contract, particularly in the situation where the participants of $s$ corrupt contract are already blackmailed, or if they are somehow obliged to the counterparty of the contract or maybe somehow jeopardized by not being involved in the corruption. Then they are more likely to participate in corruption contracts and fulfil what was promised and are less likely to disclose after the contract termination or request another performance. It follows from our approach that those seeking a counterparty to a corruption contract may intentionally create an environment where potential participants of corruption find themselves dependent or blackmailed. For example, a non-standard service is provided, that the receiver is not entitled to. The receiver of the service may later feel obligated and be more willing to engage in corrupt practices. Such a situation occurred at the Law Faculty University of West Bohemia in the Czech Republic. The faculty management (its dean and vice-deans), which was in the function in the first decade of the 21 st century, offered to some students, especially those who were already working, many non-standard services. For example, they could finish their studies earlier and were not required to perform certain duties. When the non-standard service was offered and carried out, the management asked for nothing in return. But the management later asked some of the beneficiary students to do something that at least partly violated their duties connected with their profession or position.

The people felt they owed the management and some of them seriously violated their duties. For example, several police officers had received at the faculty education enabling him working in high police position under non-standards conditions from the faculty. Later, they were asked by the faculty management to provide private or internal information that could help people connected with the management who were suspected of crimes. Some policemen complied. The suspects then could, based on the received information, took actions enabling them to avoid charges against them. Wawrosz and Otahal (2013) model the commitment of the participants of corruption based on the tragedy of commons. They note that in the previous models (e.g. Sethi and Somanathan, 1996) if the subject finds that the other is violating the rules for using the commons (e.g. common pasture, common water resources, etc.), this subject has the following options: 1 . To report a violation of the community affected by the violation. 2 . To do nothing. 3. To start breaking the rules themselves. However, Wawrosz and Otahal (2013) add that the person that discovers this also has the following option: to blackmail the violating person and to force them to participate in other illegal or immoral activities. The article emphasizes that the person who discovers this does not have to passively wait for someone to start violating a rule. They may actively create the environment forcing others to violate the rules. Appropriate means are a system of unclear or complex rules the people cannot know in detail. People can easily break the rules unintentionally in such an environment and any infringement makes them blackmailed. If somebody has the power to interpret the rules, their interpretation is decisive for what constitutes the violation of rules and the decision is not subject to independent control, their potential to blackmail others further increases. Legal rules can also limit other people's activities and thus make them corrupt. By a way of a specific example, Tullock (1996) mentions China after 1949 (after the victory of the Communist Party), where travel between provinces was restricted. Tullock believes that one of the objectives of this was to create room for taking bribes.

The above can be summarized as follows: if person $A$ is blackmailed by or dependent on another person (person $B$ ), person $B$ can use this situation to force $A$ to engage in corrupt activities or other similar forms of behaviour. Person B can, besides as the first step, deliberately create conditions under them 
others become blackmailed or dependent. The dependent or the blackmailed person is the weaker party - their range of option is limited and it is probable that they, due to dependence or extortion, will do what person B wants, including breaking the law, other duties or what based on Kant (e.g. Kant, 2016) can be called generally acceptable principles. However, it can be objected (e.g. Wawrosz, 2017) that one-sided dependency (person $A$ is dependent on person $B$ but person $B$ is not dependent on person $A$ ) is a potentially fragile relationship: person A may still be aware that their behaviour is inconsistent with morality, they may feel they are doing something wrong, and maybe tempted to end the deal or eventually eliminate the dependency, including revealing their behaviour and being prepared to be punished for it. For person $B$, it is better if person A considers the violation of generally accepted principles as something obvious commonly done by some people and what is seen, at least by part of society, as a standard way of behaviour. To achieve this person B can even inform person A about person B or another subject's engagement in illicit, immoral or similar activities. Person $A$ can then lose any barriers to the violation of laws and other generally accepted principles and will be more likely to be actively involved in activities that contradict the law or morality. Willingness to engage is further strengthened if person $A$ benefits from the engagement. Person B should not, therefore, use person A only as a means for achieving their own goals, but as a partner in activities that are convenient for both, but that is performed at the cost of a third party who is not involved in such activities. The process of the creation of corruption dependency and a corrupt environment is schematically described in Figure 1.

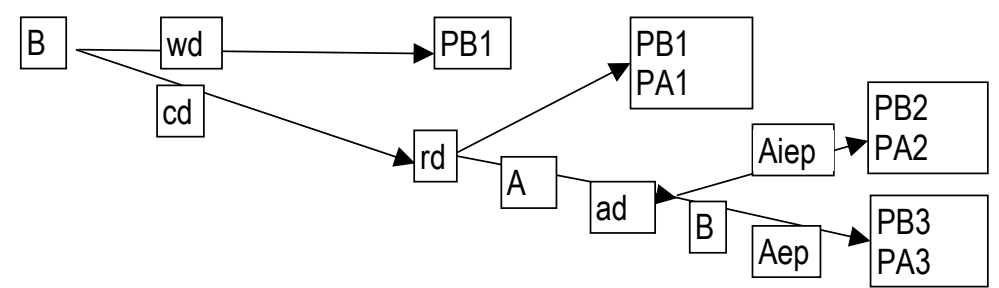

Figure 1. Creation of corruption dependency and a corruption environment

Note: $w d=A$ is not dependent on $B /$ blackmailed by $B ; c d=A$ is dependent on $B /$ blackmailed by $B$; $\mathrm{rd}=\mathrm{A}$ refuses dependency/blackmailing; $\mathrm{ad}=\mathrm{A}$ accepts dependency/blackmailing; Aiep = A does not have an equal position with $B ; A e p=A$ has an equal position with $B ; P A=$ payment of $A, P B=$ payment of $\mathrm{B}$; $\mathrm{PB} 3$ > PB2 > PB1, $\mathrm{PA} 3>\mathrm{PA} 2>\mathrm{PA} 1$

Source: own work

Based on the above, a bond (affinity) between both persons (person A and person $B$ ) is established which is characterized by great strength, even though both persons could not previously know each other or they had only weak social ties. The relationship has the following components (Wawrosz, 2017):

1. Mutual dependency: both persons (players from game theory) depend on each other and have a common secret and interest. They violate rules established by society (system), of which they are members. As part of this (greater) system, the players violating the rules form a subsystem with rules of its own. Should any of the players violate the rules of the subsystem, they run the risk of being punished, including being exposed in the greater system.

2. Mutual coverage: members of the subsystem agree that they will not inform members of the greater system of the rules violation. The main principle of violation of the subsystem discussed by us can be described as follows: «Inside their circle, they uphold the principle - I know something bad about you, you know something bad about me, therefore we both do not know anything about the other». From the economic perspective (e.g. Furubotn and Richter, 2005), members of the subsystem generally have more information than other players and they use this information advantage to the detriment of other players. 
3. Mutual favours - players give each other various favours (e.g. better information, the fulfilment of illegal activities, and above-standard treatment that is inconsistent with the rules), and these favours improve their position, income, wealth and so on in the greater system.

The relationship described above does not need to concern only two players. If it includes more players, a structure of people covering up for each other, giving each other favours, potentially blackmailing each other and violating generally accepted rules of human conduct is formed. The structure can be understood as a corruption network, but corruption usually creates only part of the structure's operation. Corruption also very often does not take its typical bribery form and is more connected with cronyism, clientelism, patronage or nepotism. It generally represents systems of services and counterservices, advantageous for their participants and at the expense of a third party (not a party to the corruption). The literature (e. g. Persson, Rothstein and Teorell, 2013) emphasizes that if such corruption networks spread throughout society the only way to reduce their impact is a «big push» involving all major political, economic, and social institutions. The ruling elite must, in this situation, lead the fight against corruption and reduce their corruption practice to a minimum.

Results. This section briefly mentions some cases of corruption structures in the Czech Republic which, in our opinion, confirm the above -i.e. that the creation of dependency or blackmail increases the willingness of dependent or blackmailed persons to participate in corruption and similar activities. Although it can be argued that the presented examples are «anecdotal evidence», they describe the real situation of mutual dependency and potential blackmailing. The first example concerns the energy company CEZ, in which the Czech state is the majority shareholder with almost $70 \%$ of the shares. However, the government performs its ownership role very weakly and, in contrast, it is the management of the company which, by its actions, influences politicians, state officials, and other persons. The company regularly sponsors various sports and cultural activities, inviting Czech politicians, officials, and other people in the public sphere to the events at the company's expense. These persons feel somewhat indebted to the company and are more willing to take actions and enforce legislation that increases the profitability of the firm. In 2011, for example, it was revealed that some members of the Budget Committee of the Chamber of Deputies of the Czech Parliament went on vacation with the company's Chief Executive Officer in Dubai, and it was likely that the Deputies' travel costs were reimbursed from corporate linked sources. Generally, the company created an environment where such practices were ordinary. Many people from the public sphere do not consider it bad to be sponsored by the company and, as counter-service, to approve norms convenient for the company but not for Czech citizens. The described collaboration between the company and politics or officials is beneficial for both parts and it creates the environment of mutual dependency. The dependent subjects make favours each other but the favours can damage non-participants of the contract. The second example is the political party «Public Things», which was represented in the Chamber of Deputies between 2010 and 2013. The informal head of the party was an entrepreneur in the field of detective and security services. It has turned out that he loaned money to some elected MPs from the party. These MPs become dependent and there was a high probability that he influenced their voting record. The entrepreneur's detective agency also spied on politicians from other parties, seeking to obtain compromising material to use against them and to force them to act in accordance with the entrepreneur's interest. Another political party, «Freedom and Direct Democracy», which has been in the Chamber of Deputies since 2013, has used similar tactics. Here the people who wanted to be a candidate for the party in the Chamber of Deputies had to inform the party leaders about anything potentially compromising in their past. The leaders justified this with the fear of a possible scandal. However, the leaders obtained information that could be used for blackmailing and influencing deputies to vote and act in a way beneficial to the leaders. People interested in candidature were willing to give up compromising information. If they were elected, they would receive a parliamentary salary and other benefits; being a Deputy was too convenient for them. 
The third example concerns one city, Liberec. Here, between 1998 and 2010, a structure of politicians and city officials on the one hand, and selected entrepreneurs on the other emerged. These people met informally and decided about the public procurements and other contracts that the city guaranteed entrepreneurs from the network were usually chosen to provide or to realize the contract. Politicians and officials who participated in the networks were given, along with other benefits, city dwellings for nonmarket rents. Having finished their duties, they often acquired a new job in one of the companies from the network. In contrast, politicians and officials who tried to limit the actions of the structure were intimidated. They were, for instance, sued by companies (members of the structure), for libel, while the municipality did not stand up for them. All of this made the network's members mutually dependent. The system was sophisticated - at the communal level, even special political parties were established to give citizens the apparent possibility to choose in municipal elections among many subjects that looked independent and anti-corrupt but were involved in corrupt activities. This example shows that competition between political parties themselves may not contribute to a reduction in corruption.

The fourth example is from the world of soccer. Here the leaders of the soccer association have shown bias in favour of clubs that voted for the leaders at the association's conferences. These clubs are more likely to receive non-investment subsidies as well as other benefits. The officials of the supporting clubs are often volunteering who are interested in soccer in their free time and participate in activities without salary. It is difficult or impossible for them to get subsidies without help from the association. If the leaders of the association arrange a subsidy for the clubs, their officials feel willing and obliged to support the association leaders. Clubs not supporting the association leaders do not receive such subsidies or receive smaller amounts. Such clubs are also subject to stricter regulatory oversight and other actions that make their operation more difficult. The structure includes certain referees too. Those who support the association's leaders are more often nominated by the association to referee football matches and can earn more money. If they make errors during a soccer match, they receive lower sanctions from the association than referees who do not support the association leaders. All here described relationships can be again seen as a mutual dependent: The association leaders are elected only if they have enough supporters. Their position comes with an appropriate salary, prestige and other benefits. Their supporters also profit from the support, as it is described above. Both parties see this behaviour as standard especially when supporters receive subsidies from the association or have some privileges as referees and do not object.

Conclusions. The main finding of this paper is that a corruption contract can emerge because of blackmailing and dependency. Blackmailing and dependency make corruption contracts more stable as a dependent or blackmailed person has something to lose if they break the conditions of the contract. Subjects wishing to participate in corruption, therefore, can create the conditions for a counterparty to become dependent or blackmailed. For instance, when the law or regulation is unclear and ambiguous everybody can be easily accused of violating the rules. Corruption is then a reasonable means to prevent such accusation or to solve its consequences when it already happens. One-sided dependence, however, can still destabilize corruption contract. The dependent person can still see corruption as an unacceptable form of human behaviour. Although it participates in a corruption contract, it can still refuse further collaboration or reveal the contract. To avoid such dangers, it is reasonable to ensure that participants of corruption contracts see corruption as something common, convenient for all parts of the contract and in accordance with accepted principles of human behaviour. Such situations contribute 1. To strengthen mutual dependency that is based not only on corruption but on mutual coverage and favours; 2 . To spread of corruption networks involving many people engaging in corruption and similar activities. If corruption is seen as the standard behaviour people lose the willingness to fight with it and it can spread in society more easily. The paper brings some examples of corruption networks from the Czech Republic fulfilling the above-mentioned characteristics. The above-presented model is based on experience from the Czech 
Republic. In other countries, there may be other mechanisms to reduce the risks of corruption contracts. However, these risks are universal. Further research should, therefore, examine in more detail how the participants in the corruption contract seek to eliminate these risks or how they hedge against them. If it is found that at least one side of a corruption contract seeks to create dependence and extortion, it is necessary to investigate the specific procedures leading to their creation. The theory must also focus on whether there is indeed an equal relationship between the parties to the corruption contract, whether it is in their interest that corruption should be understood as standard behaviour and other issues discussed in the article. It must be emphasized that such research is necessary for looking for tools for an effective fight with corruption. If corruption networks meeting the above-mentioned characteristics are spread across the entire society it is not possible to use standard methods based on increasing transparency, to reduce their influence. Transparency alone in such a situation does not lead to a decrease of corruption, because many people, although they are not engaged in corruption contracts, perceive corruption behaviour, due to its extension, as common and morally justified and they are not willing to fight with them. Transparency further makes people more aware of the problem and the extent of corruption, encouraging even formerly non-corrupt actors to take part in corruption.

Funding: The result was created in solving the student project «Synergic effect as a result of optimization on production functions depicting economic reality» using objective oriented support for specific university research of the University of Finance and Administration.

\section{References}

Acemoglu, D., \& Verdier, T. (2000). The choice between market failure and corruption. The American Economic Review, 90(1), 194211. http://dx.doi.org/10.1257/aer.90.1.194

Becker, G. S. (1968). Crime and Punishment: An Economic Approach. Journal of Political Economy, 7(2), 169-217.

Cockcroft, L. (2012). Global corruption: money, power and ethics in the modern world. London: I. B Tauris \& Co. ISBN 978-0812223101.

Dejardin, M., Laurent, H. (2016). The Ambivalent Effect of Corruption on Entrepreneurship and Economic Development. In International

OFEL Conference on Governance, Management and Entrepreneurship, 903. Available at,

http://search.proquest.com/openview/5b16e74fbc3cb696923f19d9aadfecd7/1?pqorigsite=gscholar\&cbl=2035019.

Dion, M. (2010). What is corruption corrupting? A philosophical viewpoint. Journal of Money Laundering Control, 13(1), 45-54.

Dion, M. (2013). Uncertainties and presumptions about corruption. Social Responsibility Journal, 9(3), 412-426. http://dx.doi.org/10.1108/SRJ-04-2012-0045

Di Tella, R., \& MacCulloch, R. (2006). Corruption and the Demand for Regulating Capitalists. In Rose-Ackerman, S. (Ed.), International Handbook on the Economics of Corruption (pp. 352 - 380). Cheltenham (UK): Edward Elgar Publishing. ISBN 978-184720-745-6.

Edelbacher, M., Kratcoski, P. C., \& Dobovsek, B. (2016). Corruption, Fraud, Organized Crime and the Shadow Economy. Boca Raton:

CRC Press. ISBN 978-1482255317.

Fisman, R., \& Miguel, E. (2008). How Economics Can Defeat Corruption. Foreign Policy, 168(5), 66-74

Furubotn, E. G., \& Richter, R. (2005). Institutions and Economic Theory. $2^{\text {nd }}$ Edition. Michigan: The University of Michigan Press.

Hanousek, J., \& Kochanova, A. (2015). Bribery environments and firm performance: Evidence from CEE countries, CEPR Discussion

Paper 10499. Available at, https://www.hhs.se/contentassets/7d17990209d94ae991036a603353014c/anna-kochanova.pdf.

Huntington, S. P. (1968). Political Order in Changing Societies. New Haven: Yale University Press. ISBN 0-300-01171-'7.

Jain, A. K. (2002). Corruption: A Review. Journal of Economic Surveys, 15(1), 71-121. http://dx.doi.org/10.1111/1467-6419.00133

Johnson, N., Rugers, W., Sorens, J., \& Yamarik, S. (2014). Corruption, Regulation, and Growth: An Empirical Study of the American

States. Economics of Governance, 15(1), 51-69.

Lein, D.-H. (1986). A note on competitive bribery games. Economics Letters, 22(4), 337-341.

Lui, F. (1985). An equilibrium queuing model of bribery. Journal of Political Economy, 93(4), 760-781.

Kant, I. (2016). Critique of pure reason. New York: CreateSpace Independent Publishing Platform. ISBN 978-1463794767.

Karmann, T., Mauer, R., Flatten, T. C., \& Brettel, M. (2016). Entrepreneurial Orientation and Corruption. Journal of Business Ethics, 133(2), $223-234$.

Kaufmann, D. (1997). Corruption: the facts. Foreign Policy, 107(2), 114-131. http://dx.doi.org/10.1007/s10551-014-2305-6

Klitgaard, R. (2011). Fighting corruption. CESifo DICE Report, 9(2): 31-35.

Lambsdorff, J. G. (2002). Corruption and Rent-Seeking. Public Choice, 113(1-2), 97-125.

Lambsdorff, J. G. (2007). The Institutional Economics of Corruption and Reform: Theory, Evidence and Police.Cambridge (UK): Cambridge University Press. ISBN 978-0521872751. 
Lambsdorff, J. G. (2015). Preventing Corruption by Promoting Trust - Insights from Behavioral Science. Discussion Paper, No. V-69-15 Passau: University of Passau. Available at https://www.researchgate.net/publication/286441815_Preventing_Corruption_ by_Promoting_Trust_-_Insights_from_Behavioral_Science. (Accessed 11th December 2019).

Meon, P.-G., \& Sekkat, K. (2005). Does Corruption Grease or Sand the Wheels of Growth? Public Choice, 122(1-2), 69-97.

Meon, P.-G., \& Weill, L. (2010). Is corruption an efficient grease? World Development, 38(3), 244-259.

Persson, A., Rothstein, B., \& Teorell, J. (2013). Why Anticorruption Reforms Fail - Systemic Corruption as a Collective Action Problem. Governance: An Institutional Journal of Policy, Administration and Institutions, 26(3), 449-471.

Rawls, J. (1999). Theory of Justice. $3^{\text {rd }}$ edition. Cambridge (MA): Harvard University Press. ISBN 978-0674000780.

Rose-Ackerman, S., \& Palifka, B. (2016). Corruption and Government: Causes, Consequences and Reform. Cambridge (UK): Cambridge University Press. ISBN 978-1107441095. 798.

Sethi, J., \& Somanathan, E. (1996). The Evolution of Social Norms in Common Property Use. American Economic Review, 86(4), 766-

Shleifer, A., \& Vishny, R. W. (1998). The Grabbing Hand: Government Pathologies and Their Cures. Cambridge (MA): Harvard University Press. Transparency International (2015). Fighting corruption, demanding justice. London: Transparency International.

Tullock, G. (1996). Corruption Theory and Practice. Contemporary Economic Policy, 14(3) 6-13.

Wawrosz, P. (2017). General Principles of Corruption Networks. International Advances in Economic Research, 23(1), 127-128.

Wawrosz, P., \& Otahal, T. (2013). Corruption and Competition: Toward Economic Theory of Corruption. In Spalkova, D. (Ed.), Current Trends in the Public Sector Research. Proceedings of the 17th International Conference (pp. 213 - 225). Brno: Masaryk University, Faculty of Economics and Administration, Department of the Public Administration.

World Bank (2000). World Bank Business Environment Survey (WBES). Available at, http://info.worldbank.org/governance/wbes.

Zelekha, Y. (2013). A Note on Public Sector's Corruption Equilibrium and Network Economy. Public Administration Research, 2(2), $185-$ 190. http://dx.doi.org/10.5539/par.v2n2p185

Петро Ваврош, Dr.Sc., Університет фінансів та адміністрування (Чехія).

Продуктивність сфери послуг: теоретичні та методичні аспекти зниження корупції

Корупційні договори в демократичному суспільстві визнано незаконними, а їх учасники не можуть використовувати стандартні процедури пошуку контрагентів для укладання договору, домовитись про його зміст та перевірити виконання визначених умов. У свою чергу це обумовлює зростання ризиків, пов'язаних з виконанням контракту. Учасники корупційного договору знаходяться у зоні високого ризику, оскільки кожна зі сторін може погрожувати розкриттям умов договору і денонсувати другу сторону. Зв'язок корупційного з раніше встановленим юридичним договором, як правило, розглядається як ефективний спосіб зменшення ризиків та посилення корупційного договору. У той же час, корупційний договір пов'язаний з юридичним договором, тому невиконання умов першого може поставити під загрозу юридичний договір. Так, ймовірність того, що обидві сторони корупційного договору виконають визначені умови є вищою. У статті представлено протилежний підхід, коли корупційний договір встановлюється як перший, $і$ він створює базу для подальших часто юридичних, але неправомірних договорів. Усі договори призводять до взаємовигідної колоборації всіх їі учасників, які часто стають учасниками корупційних мереж. У статmі представлено модель, в якій особа, яку шантажують, повинна брати участь у корупційних контрактах, інакше вона стикається з високою ризикованістю. Автором встановлено що з часом участь у такого роду договорах сфрормує передумови для отримання прибутку. Тим самим суб'єкти, котрі шукають контрагента по корупційному договору, часто створюють умови для шантажних ситуацій. Встановлено, що особи, які пов'язані з корупцією, втрачають свої моральні принципи розглядаючи корупцію як загальноприйняту поведінку. У статті проаналізовано існуючі корупційні схеми у Чехії. Автором наголошено, що при дослідженні корупції необхідно застосовувати комплексний підхід, включаючи взаємозалежність фракторів-впливу.

Ключові слова: шантаж, корупція, корупційні мережі, корупційні ризики, взаємна залежність.

Manuscript received: 21.06.2019.

(C) The author(s) 2019. This article is published with open access at Sumy State University. 